\title{
Characteristic of ascorbic acid in crosslinked chitosan edible film as drug delivery system membrane
}

\author{
Lilis Kistriyani*, Wahyu Sulistyawan, and Sapta Hadi Kesuma \\ Department of Chemical Engineering, Universitas Islam Indonesia, Yogyakarta, Indonesia
}

\begin{abstract}
Chitosan is a polysaccharide compound in the form of a linear polysaccharide consisting of Nacetyl glucosamine (GlcNAc) and D-glucosamine (GlcN) monomer, which is a derivative of deacetylization of chitin polymer. Chitin is one of common type of polysaccharide on earth after the excess cellulose from inveterbrata skeletons. Chitosan has anti-microbial properties. Based on this properties, chitosan is potentially used to be an edible film as drug delivery system membrane. Edible film was made by dissolving chitosan in $100 \mathrm{~mL}$ acetic acid $1 \%$, then the plasticizer and crosslinker was added while heated at $60^{\circ} \mathrm{C}$. It was molded and dried in oven at $50^{\circ} \mathrm{C}$ for 48 hours. Drug loading in the edible film could be controlled by remodeling membrane characteristics in the presence of crosslinker additions. The purpose of this study was to estimate the mass transfer coefficient $(\mathrm{kCa})$ of drug loading in various concentrations of ascorbic acid in the edible film. The characteristics of ascorbic acid in chitosan edible film could be seen from the number of drugs that could be loaded through the uv-vis spectrophotometric analysis. The higher concentration of ascorbic acid was added, the drug would be loaded more into edible film.
\end{abstract}

\section{Introduction}

In fact, the consumption of drugs is still done in a conventional way (oral). Conventional consumption of drugs has many disadvantages, such as taking a long time to reach the object and the excessive utilization of doses that can threaten drug users. This matter make a negative impact to the health of the user's body. Therefore, we need an innovation of drug consumption with utilization of edible film. Edible film is one type of membrane that can be used as drug delivery system medium. Drug Delivery System (DDS) is a term closely related to delivery of pharmaceutical compounds (drugs) in humans or animals [6]. The Drug Delivery System is usually made in a patch-shaped preparation that have characteristic like thin, elastic, and transparent for patient comfort and aesthetic side. This system can help drug users to get the same benefits in different ways. The drugs are entered into the edible film and applied in accordance with the functions of these drugs. One example of drugs that can be used is ascorbic acid which is anti-atherogenic [3].

Edible film can be produced from chitosan. Chitosan is a chemical compound derived from the chitin biological material, an organic compound that is abundant in nature after cellulose. Chitin is commonly obtained from invertebrate animal skeletons. The main source are shrimp shells, lobsters, crabs, and other shellfish in the sea. Chitosan has stronger anti-microbial properties for fungi than chitin [4]. Because of this character, chitosan produce a good edible film. Chitosan become one of the leading chemical and raw materials for industry especially for the pharmaceutical and health industries. This is possible because chitin and chitosan compounds have properties such as high coagulation and chemical reagent. Chitin and chitosan can be used in various industrial applications like additives in the fields of pharmaceutical, cosmetics, food, etc.

The main mechanism of film formation in the polysaccharides is the separation of the polymer segments and the reshape of the polymer chain into the layer or gel matrix. It is usually achieved by solvent evaporation thereby creating hydrophilic hydrogen bonds as well as electrolyte and ionic crosslinking [1]. The objectives of this research were to study the optimum concentration of ascorbic acid to drug loading, swelling precentage and estimated the mass transfer coefficient in ascorbic acid diffusion.

\section{Materials and Method}

\subsection{Materials}

The materials which used in this research were chitosan, glycerol, sodium thiosulfate, aquadest, ascorbic acid, and buffer solution.

\footnotetext{
* Corresponding author: lilis.kistriyani@uii.ac.id
} 


\subsection{Film Preparation [7]}

The process of making edible film from chitosan begins with 2 gram of chitosan dissolved in $100 \mathrm{~mL}$ $1 \%$ acetic acid solution. Then, 1.2 gram of glycerol (as plasticizer) were added and heated at $60^{\circ} \mathrm{C}$ while stirred using magnetic stirrer for 60 minutes. After 60 minutes, 0.08 gram sodium thiosulfate solution (as crosslinker) in $30 \mathrm{~mL}$ of aquadest were added periodically for 30 minutes. The heating was continued for 30 minutes and then poured into the petridish plate for film casting and entered into the oven at $60^{\circ} \mathrm{C}$ for \pm 24 hours. The dried film was inserted into the desiccator for \pm 1 day to ensure the film was completely dry and ready to be released from the mold.

\subsection{Mechanical Analysis of Edible Film [5]}

\subsubsection{Swelling test}

The $4 \mathrm{x} 4 \mathrm{~cm}$ film was immersed in a beaker glass that had been filled with a buffer solution at $\mathrm{pH}$ 7.4. Every 15 minutes the film was lifted and weighed until it was constant.

\subsubsection{Tensile strenght test and elongation}

Tensile strength and elongation testing used ASTM 882-91 procedure was measured using universal testing instrument (UTI) with load range specification 0-5000 N, extension range $0-1000 \mathrm{~mm}$, crosshead speed $100.00 \mathrm{~mm} / \mathrm{min}$.

\subsection{Drug loading Analysis [2]}

Ascorbic acid was entered into edible film by diffusion. Edible film dipped in ascorbic acid solution with various concentrations $(40 \mathrm{ppm}, 60$ ppm, $80 \mathrm{ppm}$, and $100 \mathrm{ppm}$ ) for 2 hours. Edible film that already contained drug was dried in ambient temperature. The drug loading test was performed by spectrophotometer uv-vis method using 2 cuvet pieces. The ascorbic acid solution of residual film immersion was incorporated into the cuvet and analyzed using a uv-vis spectrophotometer with a wavelength $(\lambda)$ of ascorbic acid at $256.6 \mathrm{~nm}$.

\section{Result and Discussion}

\subsection{Swelling analysis}

The addition of crosslinker in edible film would change the characteristic of edible film that caused the pores size of chitosan film were decreases. Decreasing the edible pores of the film would made an impact on the reduced absorbency of edible film.
Swelling test results on edible film could be seen from the Fig. 3.1.

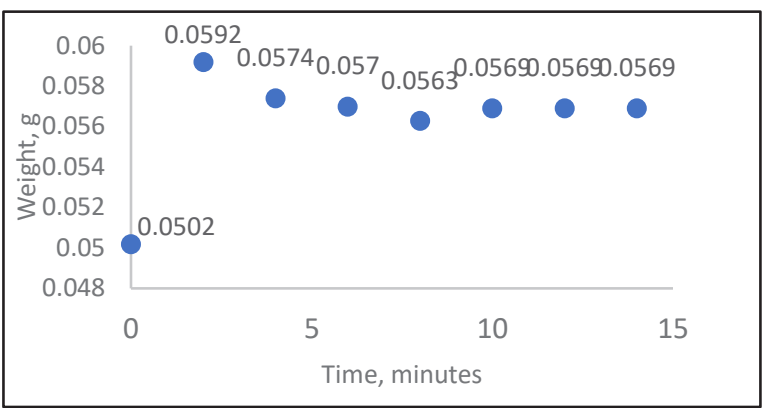

Fig. 3.1 Profile of Swelling in Various Times

Fig. 3.1 showed the results of swelling analysis from the edible film. The aims of this analysis were to determine the maximum capability of edible film to absorb liquid until the equilibrium occurs. In the first analysis, there was a significant increase in the weight of the film initially, due to the absorption of the liquid into edible films through the pores of the film. In the subsequent analysis, there was a decrease and increase until the liquid equilibrium stage was absorbed in the edible film that shown in the three last point. The absorption of liquid into edible film was about $13.3 \%$.

\subsection{Tensile strenght and elongation analysis}

A strong tensile strength test was performed to determine the maximum pressure of material that could withstand its form when it was withdrawn before it was damaged or broken. While elongation was the extent of a material that occured when it was given the power to be damaged. The results of tensile strength and elongation analysis of sequential films were $980 \mathrm{cN}$ and $17.8 \%$.

\subsection{Drug loading analysis}

The ascorbic acid in liquid was carried out into edible film by diffusion. Narrowing of the pores on edible film was formed by a sodium thiosulfate crosslinking of edible film that could retain ascorbic acid.

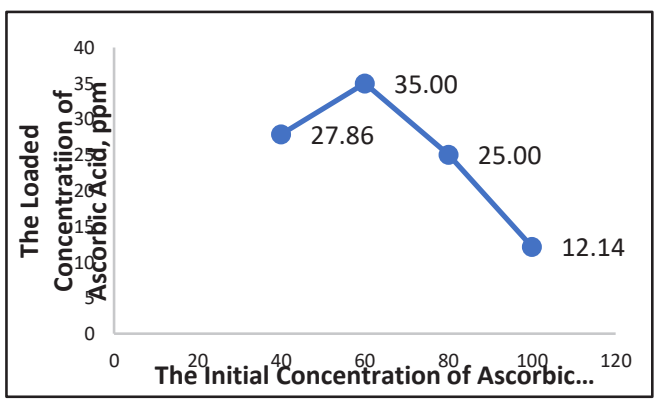

Fig. 3.2 Drug Loading Profile of Ascorbic

Figure 2 showed the results of ascorbic acid loading into edible films with initial concentrations of $40 \mathrm{ppm}, 60 \mathrm{ppm}, 80 \mathrm{ppm}$, and $100 \mathrm{ppm}$ respectively were $27.85 \mathrm{ppm}, 35 \mathrm{ppm}, 25 \mathrm{ppm}$, and 
$12.14 \mathrm{ppm}$. The amount of ascorbic acid which could be loaded into edible film had same trendline with the mass transfer coefficients $(\mathrm{kCa})$ of ascorbic acid to edible film. The ascorbic acid mass transfer coefficients $(\mathrm{kCa})$ in various concentrations were estimated with the following mass balance:

The ascorbic acid mass balance in the element volume of the membrane:

[Mass velocity input $]+[$ Mass velocity output $]=$ [Mass accumulation in the membrane]

$$
\begin{aligned}
& k\left(C^{*}-C\right) \cdot V-0=\frac{d C V}{d} \\
& k\left(C^{*}-C\right) \cdot V=V \cdot \frac{d C V}{d}
\end{aligned}
$$

With boundary conditions:

$$
\begin{gathered}
t=0 \rightarrow C=C_{0} \\
t=t \rightarrow C=C \\
\int_{C C}^{C} d=k C\left(C^{*}-C\right) t ; t=2 \text { hours } \\
\left(C-C_{0}\right)=2 \cdot k C\left(C^{*}-C\right) \\
C=\frac{2 \cdot k C \cdot C^{*}+C_{C}}{(1+2 \cdot k C)}
\end{gathered}
$$

The ascorbic acid mass balance in the solids:

[ascorbic acid in initial solid] + [ascorbic acid in initial liquid $]=$ [ascorbic acid in solid at $\mathrm{t}=$ certain $]$ + [ascorbic acid in solute at $t=$ certain]

$$
\begin{aligned}
& 0+C_{0} \cdot V=C \cdot M+C \cdot V \\
& C=\frac{V \cdot\left(C_{0}-C\right)}{M} \\
& C^{*}=H \cdot C \\
& C^{*}=\frac{H \cdot C_{0} \cdot V-H \cdot C \cdot V}{M}
\end{aligned}
$$

Equation (9) was inserted to equation (5), the equation becomes:

$$
\left[C=\frac{2 \cdot k C \cdot H \cdot C+C_{0}}{(1+2 k C)}\right]
$$

The final equation proposed to estimate mass transfer coefficient:

$$
k C=\frac{\left[\frac{C_{0}}{C}-1\right]}{2\left[1-\frac{H \cdot C}{C}\right]}
$$

Based on the equation above, the mass transfer coefficient of ascorbic acid $(\mathrm{kCa})$ in various concentrations could be calculate and gave results in Table 3.1:

Table 3.1 The mass transfer coefficient of ascorbic acid $(\mathrm{kCa})$ in various concentrations

\begin{tabular}{|c|c|}
\hline $\begin{array}{c}\text { Ascorbic Acid } \\
\text { Concentrations (ppm) }\end{array}$ & $\mathrm{kCa}(1 /$ hour $)$ \\
\hline 40 & 1.147 \\
\hline 60 & 0.70 \\
\hline 80 & 0.227 \\
\hline 100 & 0.069 \\
\hline
\end{tabular}

Based on Table 1, it could be seen that decreasing of mass transfer coefficient along with increasing of ascorbic acid concentration. As the ascorbic acid concentration was increases, less ascorbic acid could be loaded in the edible film.

\section{Conclusion}

With the addition of crosslinked can be effected the characteristics of edible film. mechanical analytic of edible film showed swelling $13.3 \%$; tensile strength $980 \mathrm{cN}$; and elongation of break $17.8 \%$. The mass transfer rate $(\mathrm{kCa})$ is inversely proportional to yhe ascorbic acid concentration being used. The optimum value of drug loading mass transfer rate is shown on the result of ascorbic acid analysis with concentration of $40 \mathrm{ppm}$ for 1.147 liter/hour.

Our greatest gratitude to the Department of Chemical Engineering, Faculty of Industrial Technology, Universitas Islam Indonesia for financial support and provide laboratory facilities to do this research.

\section{References}

1. Butler, B.L., Vernago, P.J., Testin, R.F., Bunn, J.M., \& Wiles, J.L.(1996). Mechanical and Barier Properties of Edible Chitosan Films as affected by Composition and Storage. J. Food Science. 61(5), 953-955.

2. Mishra, R. K., Datt, M., \& Banthia, A. K. (2008). Synthesis and Characterization of Pectin/PVP Hydrogel Membranes for Drug Delivery System. AAPS Pharmceutics Science and Technology, 9(2), $395-403$.

3. Naidu K.A. (2003). Vitamin C In Human Health And Disease Is Still A Mystery, An Overview. Noutrition J. 2, 7.

4. Mahatmanti, F. W., Sugiyo, W., \& Sunarto, W. (2010). Sintesis Kitosan dan Pemanfaatannya sebagai Anti Mikrobia Ikan Segar, Jurnal Sains dan Teknologi, 8(2), 101-111.

5. Purwati, Ani. (2010). Analisis Kuat Tarik dan Elongasi Plastik Kitosan Terplastisasi Sorbitol. Jurnal Teknologi, 3(2), 99-106.

6. Upadhy, G., Verma, S., Parvez, N., \& Sharma, P.K. (2014). Recent Trends in Transdermal Drug Delivery System - A Review. Advance in Biological Research, 3, 131-138.

7. Wirawan, S.K., Prasetya, A., \& Ernie. (2012). Pengaruh Plasticizer pada Karakteristik Edible Film Dari Pektin. Reaktor. 14(1), 61-67. 